\title{
Fraud Prevention Predictor on Losing Merchandise SInventory in Alfa Mart Retail Store Bandung Barat, Indonesia
}

\author{
Jhon Rinendy \\ Universitas Advent Indonesia \\ jhonrinendy@unai.edu
}

\begin{abstract}
This study aimed to examine the predictors that can be predicted to prevent the risk of fraud on losing merchandise inventory in Alfa Mart retail store within Parongpong district, Bandung-Barat through the COSO internal control dimensions (control environment control, risk assessment, control activities, information and communication, and monitoring) as perceived to prevent and reduce fraudulent acts in relation to misappropriation of assets. The survey research design was employed in this study with convenience random sampling technique. The descriptive-correlational design and multiple regression analysis were used to determine the existing relationship among the variables and the predictors of losing merchandise inventory risk. The respondents were 32 regular full-time employees of thirteen stores. There were four elements must be present to prevent fraud of losing merchandise inventory in term of administrative shrinkage, operational shrinkage, customer theft detection, and technology utilization. The findings revealed that "operational shrinkage" ranked first as a high factor, the second approach by: "administrative shrinkage," and followed by the third is the "customer theft detection" and for the last order: technology utilization. There was a positive and significant relationship between Internal Control (IC) and Fraud Prevention (FP) on losing merchandise inventory of the respondents' perception. Risk Assessment and Control Environment dimensions could be predicted to increase FP. The results indicate the importance of well-structured organizational culture of actions, policies, and procedures against fraud risk, and assessing risks of designing effective internal controls and operating internal controls in order to minimize errors and fraud by employees and customers regarding misappropriation of assets.
\end{abstract}

Keywords: Control Environment, Risk Assessment, Control Activities, Information and Communication, Monitoring, Administrative Shrinkage, Operational Shrinkage, Customer Detection, Technology Implementation.

\section{INTRODUCTION}

Fraud, as a human endeavor, involves violation of trust, rationalization, etc. (Ramamoorti \& Olsen, 2007). This shows that attention should not only be focused on finance functions, but also on the organization's internal control procedures in identifying the motives of the 
fraudster and the behavioral risk factors that may indicate fraud (Brown, 2009). In other hand, the risk of fraud was getting increased, and generally, no person was directly appointed by the company to deal with fraud issues. The results of a survey conducted by the National Retail Security in 2017 stated that lifting or stealing has been the leading cause of inventory depreciation in retail companies in The United States. Respondents reported that the largest cause was sourced from theft by consumers of $36.5 \%$, employee theft of $30 \%$, system failure or recording error $21.3 \%$, vendors of $5.4 \%$ errors, and the rest was an unknown loss of $6.8 \%$. Losses due to employees dishonest in the year 2017 reach (\$962.60) higher compared to the year 2016 worth $\$ 622$ and 2015 worth $\$ 730.92$. This shows that among the four factors, theft by consumers and employees are two factors that cause substantial harm to retail companies. In other words, losing is considered a risk of unavoidable business (Moraca, 2016). In addition, Arens, Beasley and Eldner (2008) strengthen that the biggest accounts in the retail company's financial statements are merchandise inventory accounts and the main source of revenues of retail companies. Therefore, this study was conducted taking into consideration that IC factors are aiming to protect the company's assets from damage, theft and bankruptcy.

\section{LITERATURE REVIEW}

According to Tuanakotta (2010), "the efforts to prevent fraud began from internal control. Active internal control was usually the most widely applied form of control (p. 162)". Internal controls include organizational plans, all mechanisms, methods, actions and rules that must be adhered to jointly with the aim of safeguarding the entire property of the company (Mardi, 2011). Means, internal control is necessary to prevent theft and other misappropriation of assets. In other words, the poor internal control would create a high chance of fraud risk by both internal and external companies. Therefore, good internal control can prevent and detect any fraud and provide more accurate information in decision making. Considering this, research conducted by Mufidah (2017) supported as well that internal control has a significant positive influence on fraud prevention in inventory management. Internal control aims to secure the company's assets from the risk of fraud or loss. In addition, with internal controls can ensure that the company's information is reliable and ensure that the company's operations are running well.

Furthermore, this study was conducted taking into consideration the variables of the internal control (IC) integrated framework issued by the Committee of Sponsoring Organizations (COSO) which consist four factors, such as: control environment, risk assessment, control 
activities, information and communication, and monitoring (Arens, Eldner \& Beasley, 2012). "The control environment consists of the actions, policies, and procedures that reflect the overall attitudes of top management, directors, and owners of an entity about internal control and its importance to the entity" (p.294). Risk assessment when "management assesses risks as a part of designing and operating internal controls to minimize errors and fraud" (p.297). "Control activities are the policies and procedures, including both manual and automated controls" (p.298). "Information and communication system is to initiate, record, process, and report the entity's transactions and to maintain account ability for the related assets" (p.301). "Monitoring activities deal with ongoing or periodic assessment of the quality of internal control by management to determine that controls are operating as intended and that they are modified as appropriate for changes in conditions" (p.301).

Meanwhile, activities undertaken to prevent loss of inventory (FP) variable taken by internal and external activities of the company. Internal activities include factor of administrative shrinkage and operational shrinkage. Administrative shrinkage which is randomly check inventory when recording incoming and outgoing goods, multiple administration systems, and double checks by different people. Operational shrinkage activities include: stock opname, body check with security system, recruiting employee candidate strictly, and given a good example to the subordinate. However, external activities focus on detection to theft by customers and technology implementation, such as Closed Circuit Television (CCTV), Electronic Article Surveillance (EAS), alarm, and Point of Sale (POS) (Guswai, 2018).

With regards relationship between IC and FP on losing merchandise inventory, Hall (2009) stated that adequate IC could assist the company in directing its operational activities and preventing abuse of the intent of theft. This is supported by Arens (2013) who conclude that the weakness of IC will open the opportunity to commit theft. Therefore, if the warehouse supply clerk holds the inventory record, it would be easy for them to take the inventory item and cover the theft by making adjustments to the accounting records. Thus, considering this in the management of the retail business, if the IC of the inventory is well implemented, then the risk of fraud loss of inventory can be minimized. But conversely, if IC of merchandise inventory applied is still weak, then the risk of fraud on losing the inventory will be greater. In addition, from the research conducted by Mahardani and Fitri (2014), Sukarsah (2016), and Mufidah (2017) in connection with IC and FP, it was discovered that IC has significant positive effect on FP. In other words, fraud can be prevented by adequate IC.

Statement of the Problems. 
The main objective of this study was to examine the FP factors on losing merchandise inventory risk. The fraud of losing merchandise inventory could be predicted by IC component of COSO as perceived to prevent fraudulent acts in relation to stealing of assets. Specifically, this study attempted to answer the following questions:

1. What is the level of IC dimensions of the Alfa Mart retail stores as perceived by respondents in terms of control environment, risk assessment, control activities, information and communication, and monitoring?

2. What is the level of the FP factors on losing merchandise inventory risk as perceived by respondents in terms of administrative shrinkage, operational shrinkage, customer theft detection, and technology utilization?

3. Is there a significant relationship between the degree of IC dimensions degree and the FP factors on losing merchandise inventory risk as perceived by respondents?

4. Which among the following IC dimensions significantly predict FP on losing merchandise inventory risk?

\section{METHODS}

This study employed a survey research design, which was used to collect data since this study is quantitative in nature. The descriptive-correlational design was used to determine the existing relationship among the variables (Lodico, Spaulding, \& Voegtle, 2010). To determine the best predictors among the variables on FP on losing merchandise inventory risk, the researcher used Stepwise Regression Analysis that focused on multiple coefficient of determination or R square (R2) which measured the percentage of variation in the FP factors on losing merchandise inventory that could be accounted among the variables as the predictors. IC was assigned as independent variables and the FP factors on losing merchandise inventory risk as the dependent variables that has been associated with effective operation of an organization in determining the second correlation.

The population in this study was comprised of Alfa Mart retail stores' employees who were actively working as regular full-time employees from 13 stores within Parongpong district, West Java province. Their work positions were divided into three main categories: head store, assistant head store, and rank and file (staff and non-permanent staff). The name and identity of the participating respondents were disguised in keeping with the researcher's commitment to anonymity and confidentiality. Due the limitation time and budget, the sampling method employed in this study, which was convenience random sampling technique. This technique 
was used to collect the data since among the population of the respondents, only those who were able to return the questionnaires during data gathering session were included in this study. For the final data gathering, 50 questioners were distributed and 32 returned at a rate $64 \%$. The instrument used to collect data for this research was divided into two parts. Part one was the IC questionnaires for measuring the level of control in the store. It was a modified questionnaire with six component of control (control environment, risk assessment, control activities, information and communication, and monitoring) based on IC integrated framework issued by COSO. It was a self-developed instrument designed for the purpose of this study. However, there were some items that needed to be deleted. Part two was the fraud prevention (FP) factors on losing merchandise inventory questionnaires (administrative shrinkage, operational shrinkage, detection to theft by customers and technology implementation) which was self-developed based on extensive literature review. Those questionnaires were designed with multiple-item scale measurement. Choices were indicated with 5-point alternative answer of likert-scale.

\section{RESULTS}

Internal Control Level .The level of IC per scale of the respondents garnered a "high" mean of $4.52(\mathrm{SD}=.38)$. The respondents rated their IC in their organization as high in terms of information and communication (Rank 1: $\mathrm{M}=4.70 ; \mathrm{SD}=.38$ ), control environment (Rank 2: $\mathrm{M}=4.64 ; \mathrm{SD}=.46$ ), and control activities (Rank 3: $\mathrm{M}=4.60 ; \mathrm{SD}=.63$ ). However, risk assessment (Rank 4: $\mathrm{M}=4.34 ; \mathrm{SD}=.60$ ) and monitoring (Rank 5: $\mathrm{M}=4.31 ; \mathrm{SD}=.82$ ) scale garnered an above average rating. This implies that the respondents had high IC in their retail store.

Fraud Prevention Level. The FP level of the respondents as whole was above average $(\mathrm{M}=4.22 ; \mathrm{SD}=.49)$. One out of four dimensions were high or always preventing fraud through operational shrinkage approach. However, administrative shrinkage, customer theft detection, and technology implementation were rated above average. The operational shrinkage indicator becomes an indicator with the first rank $(\mathrm{M}=4.56 ; \mathrm{SD}=.66)$, and administrative shrinkage $(\mathrm{M}=4.46 ; \mathrm{SD}=.71)$ as the second, and followed by the third is the customer theft detection $(\mathrm{M}=4.06 ; \mathrm{SD}=.51)$. And for the last order of technology utilization $(\mathrm{M}=3.79$; $\mathrm{SD}=.90)$.

Relationship among the Variables. When relating IC with FP, all ICs' dimensions were significantly correlated to all factor of the FP as indicated by its significant value ( $r=.661$, 
Sig. $=.000)$ which was less than 0.01 margin of error. Control environment $(r=.508 ; \rho<0.01$, Sig. $=.003)$, risk assessment $(r=.631 ; \rho<0.01$, Sig. $=.000)$, control activities $(r=.373$; $\rho<0.05$, Sig. $=.035)$, and information and communication $(r=.457 ; \rho<0.01$, Sig. $=.009)$ were positively and significantly related to FP. However, Monitoring $(r=.284 ; \rho<0.01$, Sig. $=.115)$ was not correlated significantly. The totality of IC prove to be positive and significant in correlation to administrative shrinkage $(\mathrm{r}=.537 ; \rho<0.01$, Sig. $=.002)$, operational shrinkage $(r=.407 ; \rho<.05$, Sig. $=.407)$, customer theft detection $(r=.616 ; \rho<0.01$, Sig. $=$ $.000)$, and technology implementation $(r=.380 ; \rho<0.05$, Sig. $=.032)$. Therefore, there is positive and significant relationship between IC and FP dimensions of the respondents' perception.

Predictors to Fraud Prevention on Losing Merchandise Inventory. Table 1 presents the total of significant predictors of FP on losing merchandise inventory among IC's dimensions. It shows that almost $50.6 \%$ of the total variance in the FP can be explain by two dimensions in IC: risk assessment (39.9\%) and control environment (10.7\%). Those component are significant proportion in this model which can be interpreted as the significant predictors to PF with total multiple correlation relationship between these predictors and PF $(71.1 \%)$.

Table 1. The Significant Predictors of FP among IC Dimensions

\begin{tabular}{|c|c|c|c|c|c|c|c|}
\hline \multirow{3}{*}{$\begin{array}{c}\text { Entering Stepwise } \\
\text { (Constant) }\end{array}$} & \multicolumn{3}{|c|}{$\begin{array}{l}\text { Unstandardize Standardized } \\
\text { d Coefficients Coefficients }\end{array}$} & \multirow[t]{2}{*}{$\mathbf{t}$} & \multirow[t]{2}{*}{ Sig. } & \multirow[t]{2}{*}{$\begin{array}{c}\mathbf{R} \\
\text { Change }\end{array}$} & \multirow[t]{2}{*}{$\mathbf{R}$} \\
\hline & B & Std. Error & Beta & & & & \\
\hline & .615 & .714 & & .860 & .397 & & \\
\hline 1 Risk assessment & .434 & .114 & .523 & 3.806 & .001 & & $9.631^{\mathrm{a}}$ \\
\hline $\begin{array}{l}2 \text { Control } \\
\text { Environment }\end{array}$ & .371 & .148 & .344 & 2.500 & .018 & .107 & $7.711^{\mathrm{b}}$ \\
\hline
\end{tabular}

\begin{tabular}{lll}
\hline a. Dependent Variable: Fraud Preventing on Losing & $\mathrm{F}=$ & Sig. $=$ \\
Inventory. Total $\mathrm{R}^{2}=.506$ & 14.811 & .000
\end{tabular}

Table 2 presents the significant predictors of prevention fraud in terms of administration shrinkage on losing merchandise inventory among IC's dimensions. It shows that administrative shrinkage on fraud prevention was explained by risk assessment. This factor accounted $38.9 \%$ of the variance in administrative shrinkage variable. Therefore, this components is significant proportion in this model which can be interpreted as the significant predictor of FP to organization administrative shrinkage in preventing fraud with total multiple correlation relationship between these predictors and pressure $62.3 \%$. 
Table 2. The Significant Predictors of Adm. Shrinkage among IC Dimension

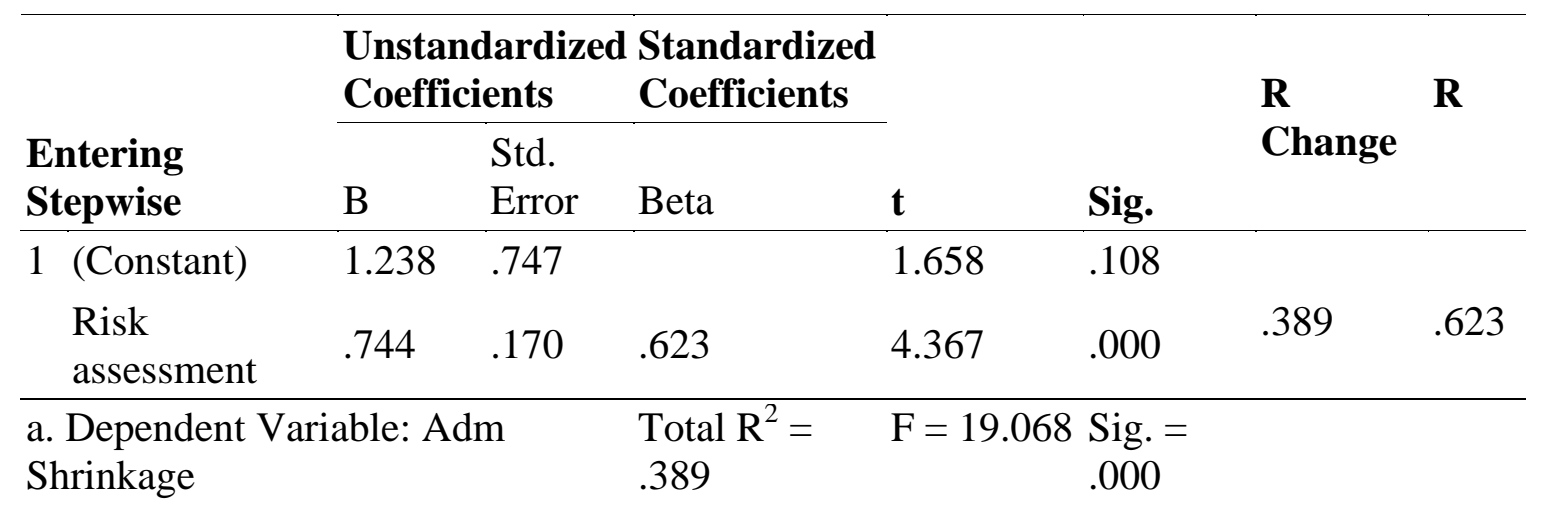

Table 3 presents the significant predictors of FP in terms of operational shrinkage among IC's dimension. It shows that operational shrinkage on FP was just explained by control environment. This factor accounted $17.2 \%$ of the variance in operational shrinkage variable with total multiple correlation relationship between this predictor and operational shrinkage (41.4\%) that can be interpreted as the significant predictor to operational shrinkage organization to prevent fraud with $\mathrm{t}$ value 2.492 and $\mathrm{Sig} .=.018$.

Table 3. The Significant Predictors of Operational Shrinkage among IC Dimension

\begin{tabular}{|c|c|c|c|c|c|c|c|}
\hline \multirow[b]{2}{*}{ Entering Stepwise } & \multicolumn{2}{|c|}{$\begin{array}{c}\text { Unstandardiz } \\
\text { ed } \\
\text { Coefficients }\end{array}$} & \multirow{2}{*}{$\begin{array}{c}\begin{array}{c}\text { Standardize } \\
\text { d } \\
\text { Coefficients }\end{array} \\
\text { Beta }\end{array}$} & \multirow[b]{2}{*}{$\mathbf{t}$} & \multirow[b]{2}{*}{ Sig. } & \multirow[t]{2}{*}{$\begin{array}{c}\text { R } \\
\text { Change }\end{array}$} & \multirow[t]{2}{*}{$\mathbf{R}$} \\
\hline & $\mathrm{B}$ & $\begin{array}{l}\text { Std. } \\
\text { Error }\end{array}$ & & & & & \\
\hline 1 (Constant) & 1.779 & 1.122 & & 1.586 & .123 & & \\
\hline $\begin{array}{l}\text { Control } \\
\text { Environment }\end{array}$ & .600 & .241 & .414 & 2.492 & .018 & .172 & .414 \\
\hline
\end{tabular}

a. Dependent Variable: Operational $\quad$ Total $\mathrm{R}^{2}=.172 ; \mathrm{F}=6.212 ;$ Sig. $=.018$ Shrinkage

Table 4 presents the significant predictors of FP in terms of customer theft detection among IC's dimensions. It shows that customer theft detection on fraud prevention in relation to IC degree was explained by two factors, namely: control environment and monitoring. Both of these factors accounted $37.7 \%$ of the variance in customer theft detection which had a significant proportion of the variation in the model. These factors can be interpreted as the significant predictors among IC dimensions of organization with customer theft detection on 
losing merchandise inventory with total multiple correlation relationship between these predictors and customer theft detection $(61.4 \%)$.

Table 4. The Significant Predictors of Customer Theft Detection among IC Dimension

\begin{tabular}{|c|c|c|c|c|c|c|c|}
\hline \multirow[b]{2}{*}{ Entering Stepwise } & \multicolumn{3}{|c|}{$\begin{array}{cc}\begin{array}{c}\text { Unstandardiz } \\
\text { ed }\end{array} & \begin{array}{c}\text { Standardiz } \\
\text { ed }\end{array} \\
\text { Coefficients } & \text { Coefficients } \\
\end{array}$} & \multirow[b]{2}{*}{$\mathbf{t}$} & \multirow[b]{2}{*}{ Sig. } & \multirow[t]{2}{*}{$\begin{array}{c}\mathbf{R} \\
\text { Change }\end{array}$} & \multirow[t]{2}{*}{$\mathbf{R}$} \\
\hline & $\mathrm{B}$ & $\begin{array}{l}\text { Std. } \\
\text { Error }\end{array}$ & Beta & & & & \\
\hline (Constant) & .620 & .851 & & .728 & .472 & & \\
\hline $\begin{array}{l}1 \text { Control } \\
\text { Environment }\end{array}$ & .509 & .162 & .459 & 3.132 & .004 & .214 & .462 \\
\hline 2 Monitoring & .252 & .091 & .404 & 2.758 & .010 & .163 & .614 \\
\hline
\end{tabular}

a. Dependent Variable: Customer $\quad$ Total $\mathrm{R}^{2}=.377 ; \mathrm{F}=8.777 ;$ Sig. $=.001$

Theft Detection

Table 5 presents the best predictors of FP in terms of technology utilization among the IC's dimensions. It shows that $13.8 \%$ of the total variance of technology utilization to FP can be explained by risk assessment with total multiple correlation relationship (37.2\%).

Table 5. The Significant Predictors of Technology Utilization among IC Dimension

\begin{tabular}{|c|c|c|c|c|c|c|c|}
\hline \multirow[b]{2}{*}{$\begin{array}{l}\text { Entering } \\
\text { Stepwise }\end{array}$} & \multicolumn{3}{|r|}{$\begin{array}{c}\text { Standardiz } \\
\text { ed } \\
\text { Coefficients }\end{array}$} & \multirow[b]{2}{*}{$\mathbf{t}$} & \multirow{2}{*}{\multicolumn{2}{|c|}{$\begin{array}{c}\text { R } \\
\text { Change }\end{array}$}} & \multirow[t]{2}{*}{$\mathbf{R}$} \\
\hline & B & $\begin{array}{l}\text { Std. } \\
\text { Error }\end{array}$ & Beta & & & & \\
\hline 1(Constant) & 1.356 & 1.120 & & 1.210 & .236 & & \\
\hline $\begin{array}{l}\text { Risk } \\
\text { assessment }\end{array}$ & .561 & .256 & .372 & 2.195 & .036 & .138 & .372 \\
\hline
\end{tabular}

a. Dependent Variable: Technology Total $\mathrm{R}^{2}=.138 ; \quad \mathrm{F}=4.818 ; \quad$ Sig. $=.036$ utilization

\section{DISCUSSION}

Internal Control. From the overall results found that the IC of the inventory was adequate to presents inventory information accurately. Considering these findings supported by Arens (2013) that the weakness of IC will open the opportunity to commit theft. Thus, considering this in the management of the retail business, if the IC of the inventory is well implemented, then the risk of fraud loss of inventory can be minimized. But conversely, if IC of 
merchandise inventory applied was still weak, then the risk of cheating loss of inventory would be greater.

Since, the level of accuracy of information and communication was adequate. It indicates that the company was expected to present accurate information and able to communicate well with each other so that the company's activities running appropriately. Therefore, the company should use the methods in recording to obtain accurate information. On other hand, employees should also understand their duties and responsibilities in order to achieved good communication. It shown that transactions was recorded with computer, and employees understand easily their duties, responsibilities and information from the superiors.

They have also control environment that includes actions, procedures, and policies in the organization which was describe the overall IC of the company and as a reflection of a good control over the supply of its merchandise inventory. It was found that the company implemented a very adequate control environment where employees adhered to company regulations and were responsible for the duties provided by the employer.

Meanwhile, they also conducted control activity approach. It was found, the company always assigns a sequential number to each document, which can be seen from the company's statement to the highest ranking. Therefore, control activity applied to the company adequately that as shown with sequential number of the documents as well as using barcodes on each good or item. On other hand, the risk assessment of the company had adopted consistently but not completely, as well as the anticipation of theft. Not all employees were able to anticipate theft. Therefore, it was necessary efforts to prevent and anticipate theft such as arranging the layout of valuables goods where closed to cashier, adding large mirrors on the wall, designing store layout that easy to watched and using security services such as security.

Finally, monitoring was almost always adequate, even some employees known already when the employer would visit the shop. Aside that, the management also monitored the quality of employees' performance and ensuring whether all employees were done with their job even still needed some improvements.

Fraud Prevention on Losing Merchandise Inventory. Regarding FP, the respondents was almost always prevent the risk of fraud on losing the merchandise inventory. The operational shrinkage indicator was found to be management's primary reason with high of scale since management were always given a good example to employees for doing a good things. The prevention conducted through administrative shrinkage was above average. It found that they 
had been safeguarding their transaction data. The stores had been securing the transactions data through the administration system. Therefore, the prevention on losing merchandise inventory had been carried out adequately. However, management was almost always doing customer theft detection, which indicated that the form of prevention to overcome the loss of goods had been applied due to customer theft. They detected fraudster through observing customers, and being able to read the customer's shopping behavior which intends to commit theft. It followed by recognizing some theft modes, and then being sensitive to buyers' movements who had indications for stealing goods, keep watching on other parts out of my works area, and providing luggage storage for customers. They also utilized technology for FP. The respondents almost always used technology such as Point of Sales (POS) system, Close Circuit Television (CCTV), electronic article surveillance (EAS) and alarm. POS system adheres standard procedures that was the most affecting indicator in preventing fraud on losing merchandise, then followed with tag sensor signal, and the last with alarm.

Relationship of IC to FP. As for the relation of IC to FP on losing merchandise inventory, there is a positive and significant relationship between IC dimensions and FP dimensions of the respondents' perception. This finding implies that respondents who are more concerned with control environment, risk assessment, control activities, and information and communication in their work environment have more able to prevent fraud risk on losing merchandise inventory through administrative shrinkage, operational shrinkage, customer theft detection and technology implementation.

Predictors to Fraud Prevention. The predictors to the fraud prevention on losing merchandise inventory among IC dimensions are found that 39.9\% (t-value: 3.806 ; Sig. $=.001)$ of the variation in FP can be explained by knowing the risk assessment of management. It is the highest and the first variable that entered regression analysis with a positive unstandardized value (.434). This positive correlation indicated that the more management control the organization with risk assessment, the higher FP on losing merchandise inventory in the store. The second variable that entered the regression analysis was control environment with 10.7\% (t-value: 2.500; Sig. $=.018$ ) contribution portion of total variance in FP. This component also had a positive unstandardized value (.371) which indicated that the more management control environment, the more fraud could be prevented on losing merchandise inventory in the organization.

Predictors to Adm. Shrinkage. This finding indicated that of the variance, "risk assessment" explained administrative shrinkage $38.9 \%$. This variable had the highest coefficient of 
determination of pressure with t-value 4.367 and Sig. value of 0.000 . The positive unstandardized coefficient (.744) of risk assessment on administrative shrinkage implies that the more concerned organization with their internal control had on the risk assessment of management, the more able management preventing fraud on losing merchandise inventory.

Predictors to Operational Shrinkage. The positive unstandardized coefficients (.600) of control environment on operational shrinkage imply that the more consistent management conducted internal control with control environment in their organization such as actions, policies, and procedures that reflect the overall attitudes of top management, directors, and owners of an entity; the more easy management preventing fraudulent activities on losing merchandise inventory.

Predictors to Customer Theft Detection. The first variable to enter the regression was control environment with t-value of -3.132 and Sig. value of .004 . This variable had a positive unstandardized value (.509) which contributed $21.4 \%$ of the variance to customer theft detection. This finding implies that the more concerned management to take actions, policies, and procedures that reflect the overall attitudes of top management, directors, and owners of an entity about internal control, the more easy management conducting fraud prevention on losing inventory. The finding is supported by Wang and Kleiner (2005) that the significant reason employees give for stealing is their perceived belief that management is stealing also, so it was acceptable for them to do so. Hence, the relationship between employees and management condition proves the point that if management wants a theft-free work environment, it must set the example of honesty and adherence to policies. The next that entered regression was monitoring with t-value of 2.758 , Sig. value of .010 , and a positive unstandardized value (.252). This variable contributed to customer theft detection by $16.3 \%$ of total variance in customer theft detection which implied that the more active management dealing periodic assessment of the quality of internal control; the more easy detecting customer to theft.

Predictors to Technology Utilization. This variable is in significant proportion of the variation in this FP level that can be interpreted as the best predictors to technology utilization for preventing fraud with t-value 2.195 and Sig. $=.036$. The positive unstandardized coefficients (.561) of this variable on technology utilization implied that the more management assessing risks operating internal controls to minimize errors and fraud, the more possible fraud prevention on losing merchandise inventory could be done. 


\section{Conclusion}

The IC level of respondents was high in their respective stores. The IC level of respondents was high in their respective stores. They would always control the business with anticipating if there were fraud occurs, and applying control consistently with information and communication, control environment, and control activities of their organization; even if almost always the store was inconsistent with its anticipating theft and consistency of implementing control in terms of the risk assessment. On the other hand, they would almost always as well in monitoring employees' activities confidentially.

The FP level of the respondents as whole was above average. The operational shrinkage indicator was found to be management's primary reason with high of scale. This factor mostly came from employer who was being a good example to employees. However, they had above average internal control on administrative shrinkage, customer theft detection, and technology implementation factor with following reasons: safeguarding their transaction data, observing customers behavior which intends to commit theft, and used technology.

When relating IC and FP variables, there is a positive and significant relationship between IC dimensions and FP degree of the respondents' perception. This means that respondents who had more concerned to their IC organization in terms of control environment, risk assessment, control activities, and information and communication were more able to prevent fraud risk on losing merchandise inventory in the organization.

\section{Recommendation}

Predictors to Administrative Shrinkage. It was found that $38.9 \%$ of the variation in the respondents' administrative shrinkage on FP could be explained as the significant predictors by risk assessment.

Predictors to Operational Shrinkage. It was found that more than $17.2 \%$ of the variation in the respondents' operational shrinkage on FP could be explained by control environment.

Predictors to Customer Theft Detection. It was also found that $37.7 \%$ of the variation in customer theft detection could be explained by two dimensions of IC, such as: control environment (6.2\%), and monitoring (2.5\%) with total correlation relationship (61.4\%).

In general, it was found that more than $50.6 \%$ of the total variance in the EFR could be explained by two (2) dimensions of IC as the significant predictors to FP, namely: risk assessment (39.9\%), and control environment (10.7\%). Thus, the predictors to the fraud prevention on losing merchandise inventory among IC dimensions are risk assessment and control environment. Risk assessment was the first and the biggest portion of the variation in 
preventing fraud on losing merchandise inventory risk than followed by control environment. Those predictors indicated that the more consistent management performing IC in terms of risk assessment and control environment, the more effective management preventing fraud on losing merchandise inventory in the organization. The results indicate the importance of wellstructured organizational culture of actions, policies, and procedures against fraud risk, and assessing risks of designing effective internal controls and operating internal controls in order to minimize errors and fraud by employees and customers regarding misappropriation of assets.

\section{REFERENCES}

Arens, Eldner \& Beasley. (2008). Auditing dan Jasa Assurance Jilid 1 Edisi 12. Jakarta: Erlangga.

Arens, Eldner \& Beasley. (2012). Auditing and Assurance Services: An Integrated Approach. $14^{\text {th }}$ Ed. Pearson Prentice Hall: Pearson Education, Inc., New Jersey.

Arens, Eldner \& Beasley. (2013). Auditing dan Jasa Assurance: Pendekatan terpadu. Jakarta: Salemba Empat.

Brown, A. (2009). Why fraud happens: and what to do about it. Accountancy Ireland:Dublin, 41(1), 30-31. Retrieved from http://www.aiias.edu:2225/ docview/223127495/134B53D9FC366B6801/1?accountid=42729

Guswai, C. (2018). How to manage retail shrinkage \& loss prevention. Jakarta: Gramedia Pustaka Utama.

Hall, J. (2009). Accounting Information System. Jakarta: Salemba Empat.

Mahardani \& Fitri, D. (2014). Pengaruh Pengendalian Intern Terhadap Pencegahan Kecurangan (Fraud) (Studi Kasus Pada PT. X Bandung). Skripsi. Fakultas Ekonomi Universitas Widyatama Bandung.

Mardi. (2011). Sistem Informasi Akuntansi. Bogor: Ghalia.

Moraca, B. (2017). 2017 National Retail Security Survey. United States: University of Florida.

Mufidah, M. (2017). Pengaruh Pengendalian Internal Persediaan dan Sistem informasi Akuntansi terhadap Upaya Pencegahan Kecurangan (Fraud) dalam pengelolaan Persediaan pada PT. Mitra Jambi Pratama. Jurnal Ilmiah Universitas Batanghari Jambi. Vol.17 (No.3); hlm 103-119.

Mufidah, M. (2017). Pengaruh Pengendalian Internal Persediaan dan Sistem Informasi Akuntansi terhadap Upaya Pencegahan Kecurangan (Fraud) dalam Pengelolaan 
Persediaan pada PT. Mitra Jambi Pratama. Jurnal Ilmiah Universitas Batanghari Jambi. Vol. 17 (No.3): hlm.103-119.

Ramamoorti, S. \& Olsen, W. (2007). FRAUD: The Human Factor. Financial Executive, 23(6), 53-55. from ABI/INFORM Global. (Document ID: 1329574871).

Sukarsah, D. (2016). Pengaruh Pengendalian Internal dan Profesionalisme Auditor Internal Terhadap Pencegahan Fraud Persediaan (Survey Pada Dua BUMN di Kota Bandung). Skripsi. Fakultas Ekoniomi Universitas Pasundan Bandung.

Tuanakotta. (2010). Akuntansi Forensik dan Audit Investigatis, Edisi 2. Jakarta:

Salemba Empat.

Wang, Y. \& Kleiner, B. H. (2005). Defining employee dishonesty. Management Research.

News, 28 (2/3). Retrieve January 22, 2012, from ABI/INFORM Global. 